\title{
Exploring Cause of Cibaduyut Image Decay as Bandung Tourist Destination for Shoe Shopping
}

\author{
Rosita* \\ Department of Resort \& Leisure Management \\ Universitas Pendidikan Indonesia \\ Bandung, Indonesia \\ rosita1019@upi.edu
}

\author{
Munny Cahyani \\ Department of Resort \& Leisure Management \\ Universitas Pendidikan Indonesia \\ Bandung, Indonesia \\ munnycahyani@rocketmail.com
}

\begin{abstract}
This study tried to explore cause of Cibaduyut image decay as Bandung tourist destination for shoe shopping from both functional and emotional components and to clarified whether image or other factor that give more influences on visiting decision. Qualitative approach was employed by interviewing 20 shoe craftsmen, 6 small-medium shoe enterprises, and 17 consumers to collect primary data. The result showed that both functional and emotional components have given impact to Cibaduyut Image. However, the image did not give effect to visiting decision.
\end{abstract}

Keywords-component; formatting; style; styling; insert (key words)

\section{INTRODUCTION}

Image was considered to be an important factor influencing tourists to visit a destination [1] [2] [3] [4]. Image itself was formed by two principal components: functional (cognitive) and emotional (affective) where functional component is related to tangible characteristics which is easily measured, while emotional component is manifested by feelings derived from individual experiences and from the processing of information on various attributes of a destination [5][6]. These two components furthermore developed to be attribute-based component and holistic component [7]. Researchers have agreed that destination image is dynamic rather than static [1] [8] [9] [10]. Several studies was conducted to explore the dynamic nature of destination image focusing on various aspects such as the role of an event or accident [11], the function of visitor experience [12], and individual's image over time [13]. However which component has given more influence to destination image change has not been clearly identified.

In the case of Cibaduyut image as a local handmade shoe shopping destination in Bandung Indonesia, the causes of its image decay were considered more from the functional component such as the product [14] [15], the enterprises [16], the management system [17], while the emotional component was ignored. This study tried to explore on both components of destination image and clarified whether image or other factor that give more influences on visiting decision.

\section{METHODS}

This study employed qualitative method by gathering secondary data from literatures including 10 journal articles, 10 online news reports, and 3 youtube videos about Cibaduyut problems related to its image directly or indirectly published between 2010 and 2015. Primary data was collected from interviewing 20 shoe craftsmen and 6 small-medium enterprises during 4 days. The data was analyzed to identify differences or changes especially in subject to the functional component. While collecting data to analyze the emotional component, interview of 17 participants was done during the same time of interviewing the craftsmen and enterprises. Demographic and psychographic characteristics of 17 participants are shown in table 1 .

TABLE I. DEMOGRAPHIC \& PSYCHOGRAPHIC CHARACTERISTICS OF PARTICIPANTS

\begin{tabular}{|c|c|}
\hline Characteristics component & $\mathrm{F}$ \\
\hline $\begin{array}{l}\text { Sex } \\
\text { Male } \\
\text { Female } \\
\end{array}$ & $\begin{array}{c}7 \\
10 \\
\end{array}$ \\
\hline $\begin{array}{l}\text { Age } \\
\qquad \begin{array}{l}20-30 \\
31-40 \\
41-50 \\
51-60 \\
\end{array}\end{array}$ & $\begin{array}{l}7 \\
3 \\
4 \\
3\end{array}$ \\
\hline $\begin{array}{l}\text { Origin } \\
\text { Bandung } \\
\text { West Java } \\
\text { Outside West Java } \\
\end{array}$ & $\begin{array}{l}8 \\
5 \\
4 \\
\end{array}$ \\
\hline $\begin{array}{l}\text { Education } \\
\text { Elementary - High school } \\
\text { College } \\
\text { Graduated } \\
\end{array}$ & $\begin{array}{l}6 \\
8 \\
3 \\
\end{array}$ \\
\hline $\begin{array}{l}\text { Occupation } \\
\text { Student } \\
\text { Housewife } \\
\text { Employee } \\
\text { Enterpreneur } \\
\end{array}$ & $\begin{array}{l}5 \\
5 \\
5 \\
2\end{array}$ \\
\hline $\begin{array}{l}\text { Visiting Cibaduyut } \\
\text { Not yet } \\
\text { One time } \\
\text { Two times } \\
\text { More than two times }\end{array}$ & $\begin{array}{l}3 \\
7 \\
4 \\
3\end{array}$ \\
\hline $\begin{array}{l}\text { Visiting purposes } \\
\text { Shopping } \\
\text { Leisure } \\
\text { other }\end{array}$ & $\begin{array}{l}5 \\
7 \\
5\end{array}$ \\
\hline
\end{tabular}




\section{FINDINGS AND DISUSSION}

Findings from both primary and secondary data indicated that cause of Cibaduyut image decay came from internal and external factors. However primary data showed several alternatives have been done to solve the problems. Those difference conditions are explained as follows.

TABLE II. FINDINGS COMPARISON

\begin{tabular}{|c|c|c|}
\hline \multirow{2}{*}{$\begin{array}{l}\text { Internal \& External } \\
\text { components }\end{array}$} & \multicolumn{2}{|c|}{ Findings Comparison } \\
\hline & Literatures (2010-2015) & Interview (2016) \\
\hline Capital & Limited amount & $\begin{array}{l}\text { Government give } \\
\text { wider access for loan }\end{array}$ \\
\hline Raw Material & $\begin{array}{l}\text { Hard to find, unstable } \\
\text { and expensive price, } \\
\text { poor quality }\end{array}$ & $\begin{array}{l}\text { Using synthetic } \\
\text { leather as subtitution, } \\
\text { buying leather on } \\
\text { sacrificial feast }\end{array}$ \\
\hline Craftsmen & $\begin{array}{l}\text { Decreasing number, } \\
\text { regeneration, lack of } \\
\text { inovasion }\end{array}$ & $\begin{array}{l}\text { Increasing number of } \\
\text { craftsmen entrants } \\
\text { but indigenous } \\
\text { craftsmen } \\
\text { regeneration is } \\
\text { threatened }\end{array}$ \\
\hline Brand & $\begin{array}{l}\begin{array}{l}\text { Have no } \\
\text { license, } \\
\text { without brand }\end{array} \\
\text { selling }\end{array}$ & $\begin{array}{l}\text { Have their own brand } \\
\text { and also produce no } \\
\text { brand product to } \\
\text { distributor }\end{array}$ \\
\hline Brand Piracy & $\begin{array}{l}\text { Copying and using } \\
\text { famous brand }\end{array}$ & $\begin{array}{l}\text { Still selling piracy } \\
\text { products with low } \\
\text { price }\end{array}$ \\
\hline Partnership & $\begin{array}{l}\text { Unfair, benefiting } \\
\text { retailer side only }\end{array}$ & $\begin{array}{l}\text { Wisely choose } \\
\text { partner and have the } \\
\text { MOU }\end{array}$ \\
\hline Buyer & $\begin{array}{l}\text { Less love of domestic } \\
\text { product, prefer low } \\
\text { price than good } \\
\text { quality }\end{array}$ & $\begin{array}{l}\text { Less love of domestic } \\
\text { product, prefer low } \\
\text { price than good } \\
\text { quality }\end{array}$ \\
\hline Competitor & $\begin{array}{l}\text { Imported shoes from } \\
\text { China, other imported } \\
\text { brand }\end{array}$ & $\begin{array}{l}\text { Imported shoes from } \\
\text { China, other imported } \\
\text { brand }\end{array}$ \\
\hline Government Policy & $\begin{array}{l}\text { Policy on leather } \\
\text { export and import, } \\
\text { loan, electricity tariff }\end{array}$ & $\begin{array}{l}\text { Policy planning for } \\
\text { small enterprises } \\
\text { mentoring }\end{array}$ \\
\hline Trade Agreement & ACFTA & ACFTA, AEC \\
\hline
\end{tabular}

Unlike the past, the shoe business in Cibaduyut now requires huge capital to survive because the transaction system is in credit. The sold products are not paid directly in cash. The results are enterprises with limited capital at a rate of tens millions rupias will have to wait for their money back to produce more shoes. It impact on the craftsmen who rely on their life only from the shoe making. They are now only earn income only when received order. At this point, working as a shoe craftsman is considered no longer able to meet the needs of everyday life. Then many shoe craftsmen switch their professions to another job that is better able to support their everyday lives. Number decreasing of shoe craftsmen is threatening the existence of knowledge and skills to make shoes for generations that have long been a tradition of indigenous people in Cibaduyut. Besides, raw material that mainly genuine leather is getting hard to find and expensive. While at the marketing level the main problems are the issue of branding and partnership. Several shoe enterprises are ignorant to arrange their brand licensing to Industrial and Trading Department, so they cannot sell their shoes with their own brand. To sell it they do a partnership with Gruty as the brand owner. However, profit share seemed unfair to them and the payment was often faltered.

In 2010 when Indonesia-China free trade system was put into effect, various brand of imported shoes flooded Indonesia. Cibaduyut retailers, which are now $90 \%$ owned by settlers, $60 \%$ are from Padang and $30 \%$ are from outside West Java, only $10 \%$ owned by indigenous people of Cibaduyut, are only concerned about the economic aspects of their business which is profit. Compare to Cibaduyut shoes, the purchase price of imported shoes are much cheaper. It means by selling imported shoes with the relative same price the retailers can earn higher profits. At the end, the Cibaduyut shoes production that have been declining become more down since high production rates cannot be suppressed and it cause high prices that do not provide many advantages for the retailers. On the other hand, buyers are now offered more choices of brand and price. They are likely to be fond of the imported brand since it has more stylish and modern in fashion and also cheaper.

Result from interviewing 20 shoe craftsmen, and 6 shoe enterprises showed several differences, especially at the level of marketing. Unfair partnership that only give benefit on one side is now getting left behind. They are now more aware of branding and get benefit from it. They can choose partner to distribute and market their products wisely based on mutual beneficial. Some distributors work with them are owners of famous brand and their market are very large across Indonesia. Internet also help them to market their products widely all over the world by themselves. They have already use several online shopping sites and even create their own sites to market their products.

At the production level the unstable and high price of raw material and capital are considered still be a problem. However, they tried to solve it by using synthetic leather imported from China, while capital problem is now received special attention from the government. State banks facilitate small-medium enterprises by giving them credit loans. It is ranging from 500 million rupiah to 15 billion rupiah with repayment rate of $98 \%$. Beside the two problems above, the number of shoe craftsmen is also still considered insufficient since many switch profession at any time they think can get better pay from other jobs, but now settler from various area in West Java are getting employed. It is good at one side but bad for another, especially in a subject of regeneration of indigenous craftsmen and their traditional skills. This problem effected on innovation since young generation of Cibaduyut now prefer to get another job and most older craftsmen who still working found difficulties on making shoes in new model. Several small enterprises have already had their own brand, but most of them still produce no brand product due to high price of brand licensing. As a short cut several dishonest enterprises produced and copying famous brand products and sell them with very low price. China imported shoes are still 
become number one competitor since their products are cheaper and more fashionable especially on women and children shoes. Moreover, after ACFTA, in 2016 AEC was also put into effect which enable products from Malaysia and other ASEAN countries become new competitors to Cibaduyut.

Unfortunately, consumer as the main component in forming Cibaduyut image seems to be neglected by researchers and journalists. The consumers, especially Indonesian, were assumed prefer more to purchase imported products because considered more prestigious and yet cheaper on some case such as China products. Was it a real fact or just an assumption? There is no research found to clarify it yet. So, here one attempt to clarify above assumption based on the data. 17 participants interviewed answered they know Cibaduyut and its image was as shoe shopping area, but only 11 of them knew about the handmade shoes' production in this area. When questioned again about which country made shoes they wore, all of them checked it first, then 9 of them answered that it was made in China (5), Vietnam (2), USA (1), and UK (1). The rest of 8 participants could not find the country name made their shoes, so they assumed it was made in Indonesia. They were also questioned about their preference when purchasing a pair of shoes. Most of them (14) answered model as their first preferences and the rest 3 participant preferred fit feeling came the first. Their answers indicated that "made in" or "made of" title never be their first priority. Moreover, when they asked again which one they will choose between imported and domestic products? All of them (17) answered to choose domestic one. Here, we found that Indonesian consumers' less love of domestic production was just an assumption and not the real fact. Furthermore, one tried to find out more the reasons they choose domestic product. They explained it with different words but have one similar meaning which is feeling of nationality as Indonesian. However, some (3) explained several cases where they could only buy imported product or trusted brand such as ballet shoes and sport shoes. The last question to be asked was whether they will go to Cibaduyut to purchase shoes and why for both answers "yes" or "no". All of participants (17) said "no" and 9 of them with "but" they will go when they need to order shoes with specific model they want. The reasons were mostly (14) because they can purchase shoes at many stores at malls or shopping centers and the rest 3 of them answered that Cibaduyut is not around their neighborhood or impractical to go to a such distance place only to buy a pair of shoes. Above result clearly indicated that although consumers have the image of Cibaduyut as a shoe shopping area, but it does not make them to go there to purchase products, and the reason why they are not going is more because there are alternative places around that considered more practical to them to access and purchase the same products.

The last participants' answer implied that consumers now need more than just "one attraction" to influence their decision to go to a destination. They preferred malls or shopping centers not only to buy shoes, but also to fulfill their other needs such as window shopping, bring their children to have fun, or to have a cup of coffee in a coffee bar. One thing also need to be taken as an account is that several research have found Asians had stronger impulsive buying behavior than Caucasians, especially people living in developed countries [18] [19] [20]. So it make sense that consumers chose not to go to Cibaduyut since they found there were not many attractions or activities they could do there beside purchasing shoes. Although shopping sometimes could be the main motivation for a tourist to go to a destination, but a destination should be able to provide services for various tourists' needs attached to their motivation of shopping.

\section{CONCLUTION}

The internal and external problems faced by Cibaduyut have given impacts to its image. It is decaying from Bandung most famous handmade leather shoes center in 1990s era to only a shoe shopping center now. The last image is one attached to many Indonesian consumers (17:11). This image do not give effect on their visiting decision. The reason is more on the attraction provide by Cibaduyut as a destination that cannot fulfill their various needs beside purchasing shoes. However, this study still have its limitations, especially in quantitative data with larger samples. So it need an extended study in quantitative data analysis to provide more valid evidence on this result.

\section{ACKNOWLEDGMENT}

Thank you to Mrs. Fitri Rahmafitria as the Head of Resort \& Leisure Management Department, Universitas Pendidikan Indonesia that has given authors chance and support to do the research. Thank you too to all participants that give big contribution in gathering the data.

\section{REFERENCES}

[1] S. Baloglu and K. W. McCleary,"A model of destination image formation," Annals of Tourism Research, vol. 26 Issue 4, pp. 868-897, October 1999.

[2] M. J. Sirgy and C. Su, "Destination image, self-congruity, and travel behaviour; toward an integrative model," Journal of Travel Research, vol. 38 no. 4 , pp. $340-352$, May 2000.

[3] A. D. A. Tasci and W. C. Gartner, "Destination image and its functional relationships, Journal of Travel Research, vol. 45 no. 4, pp. 413-425, May 2007.

[4] C. Chen and D. Tsai, "How destination image and evaluative factors affect behavioural intentions," Tourism Management, vol. 28 Issue 4, pp. 1115-1122, August 2007.

[5] S. H. Kennedy, "Nurturing corporate image," European Journal of Marketing, vol. 11 no. 3, pp.120-64, 1977.

[6] G. LeBlanc and N. Nguyen, "Cues used by customers evaluating corporate image in service firms," International Journal of Service Industry Management, vol. 7 no. 2, pp. 44-56, 1996

[7] C.M. Echtner and J. R. Ritchie, "The meaning and measurement of destination image," Journal of Tourism Studies, vol. 14 Issue 1, May 2003

[8] M.G. Gallarza, I.G. Savra, and .C. Garcia, "Destination image: towards a conceptual framework," Annals of Tourism Research, vol. 29 Issue 1, pp. 56-78, January 2002.

[9] C. Ryan and J. Cave, "Structuring destination image: a qualitative approach," Journal of Travel Research, vol. 44 no. 2, pp. 143-150, November 2005.

[10] A.D.A. Tasci, W.C. Gartner, and S. T. Cavusgil, "Conceptualization and operationalization of destination image," Journal of Hospitality and Tourism Research, vol. 31 no.2, pp. 194-223, May 2007. 
[11] Kim, S. S., \& Morrsion, A. M. (2005). Change of images of South Korea among foreign tourists after the 2002 FIFA World Cup. Tourism Management, 26(2), 233-247.

[12] Y.Yilmaz, E. T. İçigen, Y. Ekin, and B. D. Utku, "Destination image: A comparative study on pre and post trip image variations, Journal of Hospitality Marketing \& Management, vol. 18(3), pp. 461-479, 2009.

[13] N. Chen, S. Ji and D.C. Funk, "An extended study on destination image decay of sport tourists over time," Journal of Destination Marketing and Management, vol. 2 issue 4, pp. 241-251, January 2014

[14] S. Arief and A. R Mulyana, "Re-Branding kawasan Cibaduyut," Reka Makna, vol. 1 no. 1, pp. 1-12, 2013

[15] R. R. Hidayat and A. B. Sriwarno, "Brand development strategy of microscale shoe industries based on augmented reality for smartphone application,” Jurnal Sosioteknologi, vol. 14 no. 1, pp. 89-97, 2015

[16] G. U Sumantri and R. A. Nasution, "barriers in adopting original brand manufacturing practice among Indonesia's footwear SMEs, Proceedings of $4^{\text {th }}$ Asia-Pacific Business Research Conference, pp. 111, October 2013

[17] N. G. M. Kerti Utami, "Pengembangan industri kreatif di kota Bandung melalui klaster wisata," Barista Jurnal Kajian Bahasa dan Pariwisata, vol. 1 no. 2 , pp. $1-18,2014$

[18] J. J. Kacen and J. A. Lee, "The influence of culture on consumer impulsive buying behavior,' Journal of Consumer Psychology, vol. 12 no. 2, pp. 163-176, 2002.

[19] T. Jalees, "An empirical analysis of impulsive buying behavior in Pakistan," International Review of Business Research Papers, vol. 5 no. 6, pp. 298-308, 2009.

[20] C. Pornpitakpan and J. H. Han, "The effect of culture and salesperson's retail service quality on impulse buying," Australasian Marketing Journal, vol. 21, pp. 85-93, 2013. 